\title{
One hundred consecutive pneumonectomies after induction therapy for non-small cell lung cancer: An uncertain balance between risks and benefits
}

Christophe Doddoli, MD, ${ }^{\text {a,d }}$ Fabrice Barlesi, MD, ${ }^{b}$ Delphine Trousse, MD, ${ }^{\text {a }}$ Stéphane Robitail, MD, ${ }^{c}$ Sadio Yena, MD, ${ }^{a}$ Philippe Astoul, MD, PhD, ${ }^{b}$ Roger Giudicelli, MD, ${ }^{a}$ Pierre Fuentes, MD, and Pascal Thomas, MD ${ }^{a},{ }^{a}$

From the Departments of Thoracic Surgery, ${ }^{\mathrm{a}}$ Oncology, ${ }^{\mathrm{b}}$ and Medical Information \& Biostatistics, ${ }^{c}$ Université de la Méditerranée (Aix-Marseille II), Faculty of Medicine, Sainte-Marguerite Hospital, Assistance Publique-Hôpitaux de Marseille, Marseille, France, and UPRES EA 2201, ${ }^{\mathrm{d}}$ IFR Jean Roche, Marseille, France.

Received for publication Sept 3, 2004; revisions received Oct 27, 2004; accepted for publication Nov 23, 2004.

Address for reprints: Christophe Doddoli, MD, Service de Chirurgie Thoracique, Hôpital Sainte-Marguerite, 270, Bd de Sainte-Marguerite, 13274 Marseille Cedex 09, France (E-mail: christophe.doddoli@ mail.ap-hm.fr).

J Thorac Cardiovasc Surg 2005;130:416-25

$0022-5223 / \$ 30.00$

Copyright (c) 2005 by The American Association for Thoracic Surgery

doi:10.1016/j.jtcvs.2004.11.022
Objective: We sought to assess postoperative outcome after pneumonectomy after neoadjuvant therapy in patients with non-small cell lung cancer.

Methods: This retrospective study included 100 patients treated from January 1989 through December 2003 for a primary lung cancer in whom pneumonectomy had been performed after an induction treatment. Surgical intervention had not been considered initially for the following reasons: N2 disease (stage IIIA, $\mathrm{n}=79$ ), doubtful resectability (stage IIIB [T4, N0], $\mathrm{n}=19$ ), and M1 disease (stage IV [T2, N0, M1, solitary brain metastasis], $\mathrm{n}=2$ ). All patients received a 2-drug platinumbased regimen with a median of 2.5 cycles (range, 2-4 cycles), and 30 had associated radiotherapy (30-45 Gy).

Results: There were 55 right and 45 left resections. Overall 30-day and 90-day mortality rates were $12 \%$ and $21 \%$, respectively. At multivariate analysis, one independent prognostic factor entered the model to predict 30-day mortality: postoperative cardiovascular event (relative risk, 45.7; 95\% confidence interval, 3.7-226.7; $P=.001$ ). Four variables predicted 90 -day mortality: age of more than 60 years (relative risk, 5.06; 95\% confidence interval, 1.47-17.48; $P=.01$ ), male sex (relative risk, 8.25; 95\% confidence interval, 1.01-67.34; $P=.049$ ), postoperative respiratory event (relative risk, 3.64; 95\% confidence interval, 1.14-9.37; $P=.007$ ), and postoperative cardiovascular event (relative risk, 7.84; 95\% confidence interval, 3.12-19.71; $P<$ .001 ). Estimated overall survivals in 90-day survivors were 35\% (range, 29\%-41\%) and $25 \%$ (range, $19.3 \%-30.7 \%$ ) at 3 and 5 years, respectively. At multivariate analysis, one independent prognostic factor entered the model: pathologic stage III-IV residual disease (relative risk, 1.89; 95\% confidence interval, 1.09-3.26; $P=.022$ ).

Conclusions: Pneumonectomy after induction therapy is a high-risk procedure, the survival benefit of which appears uncertain.

$\mathrm{T}$ The treatment of patients with locally advanced non-small lung cancer remains a challenge. The current efforts relate essentially to the evaluation of induction therapy. ${ }^{1-5}$ The purpose of such therapy is (1) to decrease the tumor volume and, in turn, to provide the best chances for a complete resection (R0), leaving no identifiable residual disease, and (2) to control a potentially micrometastatic disease in distant organs. Even if the response to the induction therapy and survival are not rigorously correlated, it seems that improvement in survival is mainly observed in those patients in whom the disease has been downstaged by the preoperative treatment. ${ }^{6}$ However, this long-term benefit is of modest magnitude and could be offset by the cumulated toxicity of combined treatment modalities. We previously reported that surgical intervention after induction therapy was associated with an increased operative risk, ${ }^{7}$ and many reports dealing with that issue have been published. However, only few data are available regarding pneumonectomy, 
TABLE 1. Variables predicting 30 day-mortality

\begin{tabular}{|c|c|c|c|c|c|c|c|}
\hline \multirow[b]{2}{*}{ Variable } & \multirow[b]{2}{*}{ Levels } & \multirow{2}{*}{$\begin{array}{l}\text { Crude } \mathrm{HR}^{*} \\
\text { estimate }\end{array}$} & \multirow[b]{2}{*}{$95 \% \mathrm{Cl}$} & \multicolumn{3}{|c|}{ Adjusted HR } & \multirow[b]{2}{*}{$P$ value } \\
\hline & & & & $P$ value & estimate & $95 \% \mathrm{Cl}$ & \\
\hline \multirow[t]{2}{*}{ Age } & $\leq 60 \mathrm{y}$ & 1 & & & & & \\
\hline & $>60 y$ & 3.05 & $0.83-11.27$ & .09 & & & \\
\hline \multirow[t]{2}{*}{ Sex } & Male & 2.28 & $0.3-17.69$ & .43 & & & \\
\hline & Female & 1 & & & & & \\
\hline \multirow[t]{2}{*}{ Preoperative RT } & Yes & 1 & & & & & \\
\hline & No & 1.34 & $0.36-4.93$ & .67 & & & \\
\hline \multirow[t]{2}{*}{ Resection } & Standard & 1 & & & & & \\
\hline & Extended & 1.37 & $0.30-6.26$ & .68 & & & \\
\hline \multirow[t]{2}{*}{ Operation } & EPR & 1.48 & $0.45-4.91$ & .52 & & & \\
\hline & IPR & 1 & & & & & \\
\hline \multirow[t]{2}{*}{ Side of resection } & Right & 2.65 & $0.72-9.8$ & .14 & & & \\
\hline & Left & 1 & & & & & \\
\hline \multirow[t]{2}{*}{ Bronchial suture reinforcement } & Yes & 1 & & & & & \\
\hline & No & 2.43 & $0.66-8.99$ & .18 & & & \\
\hline \multirow[t]{2}{*}{ Pathologic stage } & $0, \mathrm{I}, \mathrm{II}$ & 1.04 & $0.33-3.21$ & .95 & & & \\
\hline & III, IV & 1 & & & & & \\
\hline \multirow[t]{2}{*}{ PO respiratory event } & Yes & 7.4 & $2.3-23.2$ & .001 & & & \\
\hline & No & 1 & & & & & \\
\hline \multirow[t]{2}{*}{ PO cardiovascular event } & Yes & 45.7 & $5.9-355$ & $<.001$ & 29 & $3.7-226.7$ & .001 \\
\hline & No & 1 & & & 1 & & \\
\hline \multirow[t]{2}{*}{ PO surgical complication } & Yes & 2.4 & $0.64-8.74$ & .2 & & & \\
\hline & No & 1 & & & & & \\
\hline \multirow[t]{2}{*}{ Blood transfusion } & Yes & 1 & & & & & \\
\hline & No & 0.01 & $0-1.40$ & .07 & & & \\
\hline \multirow[t]{2}{*}{ Period of the study } & 1989-1997 & 1.04 & $0.33-3.28$ & .95 & & & \\
\hline & $1998-2003$ & 1 & & & & & \\
\hline
\end{tabular}

$H R$, Hazard ratio; $\mathrm{Cl}$, confidence interval; $R T$, radiotherapy; $E P R$, extrapericardial route; $I P R$, intrapericardial route; $P O$, postoperative. ${ }^{*}$ Estimates obtained by running the model with one independent variable at a time.

which makes generalizations difficult. ${ }^{6,8-19}$ Most articles reported on small case series ${ }^{8-12,14,16,17}$ with sometimes all kinds of lung resection and without emphasis on those patients who received pneumonectomy. ${ }^{6,13,15}$ Moreover, the usual markers of postoperative mortality (30-day and in-hospital mortality) might reflect the risks of the procedure insufficiently. Indeed, treatment-related mortality should also include all deaths occurring as a direct consequence of a complication or sequel of surgical intervention, whatever the delay from the surgical procedure. In that way, 90-day mortality was used recently to emphasize the risks of right pneumonectomy after neoadjuvant therapy for lung cancer. ${ }^{18}$ Thus we conducted this study to assess the risk/benefit ratio of combined therapies, including pneumonectomy, in terms of 30-day and 90-day mortality and long-term survival in patients with non-small cell lung cancer.

\section{Patients and Methods \\ Patients}

The medical records of 100 consecutive patients who underwent pneumonectomy after neoadjuvant therapy for a primary lung cancer were reviewed for the 15-year period ranging from January 1989 through December 2003. Patient charts were identified by screening of a database into which data were entered prospectively for any patient undergoing surgical intervention for thoracic malignancy at our department.

There were 83 male and 17 female subjects, whose ages ranged from 32 to 76 years (mean, $57 \pm 10$ years). Surgical intervention had not been considered initially for the following reasons: N2 disease (IIIA, $\mathrm{n}=79$ ), doubtful resectability (stage IIIB [T4, N0], $\mathrm{n}=19$ ), and M1 disease (stage IV [T2, N0, M1, solitary brain metastasis], $n=2$ ). These 2 patients were previously operated on for their cerebral disease.

All patients received a 2-drug platinum-based regimen. Combination was done with vinorelbine in 46 patients, etoposide in 25 patients, gemcitabine in 15 patients, and paclitaxel in 14 patients. A median of 2.5 cycles (range, 2-4 cycles) was administrated. Thirty patients received thoracic radiotherapy with neoadjuvant chemotherapy at doses ranging from 30 to $45 \mathrm{~Gy}$.

Among the 79 patients who were considered initially to have N2 disease, only 25 (31.6\%) had pathologically proved mediastinal node involvement. Other cases were staged as $\mathrm{cN} 2$ on the basis of computed tomographic (CT) scan findings only. None of these patients had a positron emission tomographic scan because this technology was not available routinely in our city before June 2004. Similarly, the diagnosis of a cT4 N0 disease $(n=19)$ was established on the basis of bronchoscopic and CT scan findings. 
TABLE 2. Variables predicting 90-day mortality

\begin{tabular}{|c|c|c|c|c|c|c|c|}
\hline \multirow[b]{2}{*}{ Variable } & \multirow[b]{2}{*}{ Levels } & \multirow{2}{*}{$\begin{array}{c}\text { Crude } \mathrm{HR}^{*} \\
\text { estimate }\end{array}$} & \multirow[b]{2}{*}{$95 \% \mathrm{Cl}$} & \multicolumn{3}{|c|}{ Adjusted HR } & \multirow[b]{2}{*}{$P$ value } \\
\hline & & & & $P$ value & estimate & $95 \% \mathrm{CI}$ & \\
\hline \multirow[t]{2}{*}{ Age } & $\leq 60$ y & 1 & & & 1 & & \\
\hline & $>60 y$ & 6.85 & $2.02-23.30$ & .002 & 5.06 & 1.47-17.48 & .01 \\
\hline \multirow[t]{2}{*}{ Sex } & Male & 4.5 & $0.6-32.42$ & .14 & 8.25 & $1.01-67.34$ & .049 \\
\hline & Female & 1 & & & 1 & & \\
\hline \multirow[t]{2}{*}{ Preoperative $\mathrm{RT}$} & Yes & 1.11 & $0.45-2.76$ & .81 & & & \\
\hline & No & 1 & & & & & \\
\hline \multirow[t]{2}{*}{ Resection } & Standard & 1 & & & & & \\
\hline & Extended & 1.64 & $0.55-4.87$ & .38 & & & \\
\hline \multirow[t]{2}{*}{ Operation } & EPR & 1.6 & $0.65-3.96$ & .31 & & & \\
\hline & IPR & 1 & & & & & \\
\hline \multirow[t]{2}{*}{ Side of resection } & Right & 1.87 & $0.76-4.64$ & .18 & & & \\
\hline & Left & 1 & & & & & \\
\hline \multirow[t]{2}{*}{ Bronchial suture reinforcement } & Yes & 1 & & & & & \\
\hline & No & 1.73 & $0.7-4.28$ & .24 & & & \\
\hline \multirow[t]{2}{*}{ Pathologic stage } & $0, \mathrm{I}, \mathrm{II}$ & 1.13 & $0.48-2.67$ & .78 & & & \\
\hline & III, IV & 1 & & & & & \\
\hline \multirow[t]{2}{*}{ PO respiratory event } & Yes & 3.84 & $1.59-9.29$ & .003 & 3.64 & $1.14-9.37$ & .007 \\
\hline & No & 1 & & & 1 & & \\
\hline \multirow[t]{2}{*}{ PO cardiovascular event } & Yes & 6.78 & 2.84-16.2 & $<.001$ & 7.84 & $3.12-19.71$ & $<.001$ \\
\hline & No & 1 & & & 1 & & \\
\hline \multirow[t]{2}{*}{ PO surgical complication } & Yes & 2.27 & $0.83-6.19$ & .11 & & & \\
\hline & No & 1 & & & & & \\
\hline \multirow[t]{2}{*}{ Blood transfusion } & Yes & 4.09 & $1.5-11.2$ & .006 & & & \\
\hline & No & 1 & & & & & \\
\hline \multirow[t]{2}{*}{ Period of the study } & 1989-1997 & 1 & & & & & \\
\hline & 1998-2003 & 1.04 & $0.44-2.47$ & .93 & & & \\
\hline
\end{tabular}

$H R$, Hazard ratio; $C l$, confidence interval; $R T$, radiotherapy; $E P R$, extrapericardial route; $I P R$, intrapericardial route; $P O$, postoperative. *Estimates obtained by running the model with one independent variable at a time.

Among the 19 patients with cT4 disease, 8 had a pretreatment mediastinoscopy to rule out $\mathrm{N} 2$ disease, a nonresectable mediastinal invasion, or both.

Histology was squamous cell carcinoma in 49 patients, adenocarcinoma in 34 patients, and undifferentiated carcinoma in 17 patients. Nine patients had a preoperative mediastinoscopy or a remediastinoscopy to rule out $\mathrm{N} 2$ disease.

Adjuvant therapy was performed under the care of referring physicians, and therefore no uniform protocol was used. Adjuvant radiotherapy, chemotherapy, or associated radiochemotherapy was administered in 18,6 , and 14 patients, respectively.

\section{Statistical Analysis}

The following variables were considered as potential prognostic factors of 30- and 90-day mortality and survival: age ( $\leq 60$ vs $>60$ years), sex, postoperative stage ( 0 , I, and II vs III and IV), type of induction therapy (chemotherapy vs radiochemotherapy), side of resection, type of resection (standard vs extended; intrapericardial vs extrapericardial route), reinforcement of the bronchial suture, postoperative respiratory event (bronchopulmonary obstruction, atelectasis, pneumonia, postpneumonectomy edema, adult respiratory distress syndrome, pneumothorax in the remaining lung, or pulmonary embolism), postoperative cardiovascular event (arrhythmias, cardiac failure [whatever the origin], myocardial infarc- tion, deep vein thrombosis, or stroke), postoperative surgical complication (haemothorax, bronchopleural fistula, empyema, or cardiac luxation), perioperative allogeneic blood transfusion, and the period of the study (1989-1997 vs 1998-2003). Survival was estimated by using the product limit method of Kaplan-Meier. Univariate and multivariate analyses were performed by using the Cox proportional hazards regression model to determine factors potentially predicting postoperative mortality (30- and 90-day mortality) and survival. The Cox model was used to incorporate in the same model any explanatory variables with a $P$ value of less than .20. Forward stepwise procedure and likelihood ratio tests were used to select the variables with the greatest prognostic value $(P<.05)$. Univariate and multiple logistic regression analysis was performed to obtain factors potentially predicting postoperative respiratory event or cardiovascular event and to adjust the odds ratio for each risk factor while controlling for the potential influence of others variables. This statistical analysis was performed with the SPSS V10.0 software package (SPSS Inc, Chicago, Ill).

\section{Results}

\section{Surgical Procedure}

Two patients were operated on before the completion of the neoadjuvant treatment because of a complication 
TABLE 3. Variables predicting postoperative respiratory events

\begin{tabular}{|c|c|c|c|c|c|c|c|}
\hline \multirow[b]{2}{*}{ Variable } & \multirow[b]{2}{*}{ Levels } & \multirow{2}{*}{$\begin{array}{l}\text { Crude } \mathrm{OR}^{*} \\
\text { estimate }\end{array}$} & \multirow[b]{2}{*}{$95 \%$ CI } & \multicolumn{3}{|c|}{ Adjusted OR } & \multirow[b]{2}{*}{$P$ value } \\
\hline & & & & $P$ value & estimate & $95 \% \mathrm{CI}$ & \\
\hline \multirow[t]{2}{*}{ Age } & $\leq 60$ y & 1 & & & & & \\
\hline & $>60 y$ & 2.45 & $0.85-7.09$ & .09 & & & \\
\hline \multirow[t]{2}{*}{ Sex } & Male & 1 & $0.4-4.88$ & 6 & & & \\
\hline & Female & 1.4 & & & & & \\
\hline \multirow[t]{2}{*}{ Preoperative RT } & Yes & 1.95 & $0.69-5.49$ & .20 & 3.84 & $1.09-13.55$ & .04 \\
\hline & No & 1 & & & 1 & & \\
\hline \multirow[t]{2}{*}{ Resection } & Standard & 1 & & & & & \\
\hline & Extended & 1.33 & $0.33-5.40$ & .69 & & & \\
\hline \multirow[t]{2}{*}{ Operation } & EPR & 1.09 & $0.35-3.40$ & .88 & & & \\
\hline & IPR & 1 & & & & & \\
\hline \multirow[t]{2}{*}{ Side of resection } & Right & 2.73 & $0.9-8.29$ & .08 & & & \\
\hline & Left & 1 & & & & & \\
\hline \multirow[t]{2}{*}{ Bronchial suture reinforcement } & Yes & 1 & & & & & \\
\hline & No & 3.48 & $1.06-11.40$ & .04 & & & \\
\hline \multirow[t]{2}{*}{ Pathologic stage } & $0, \mathrm{I}, \mathrm{II}$ & 1 & & & & & \\
\hline & III, IV & 1.08 & $0.40-2.95$ & .87 & & & \\
\hline \multirow[t]{2}{*}{ PO cardiovascular event } & Yes & 4.89 & $1.69-14.12$ & .003 & 4 & $1.25-12.88$ & .02 \\
\hline & No & 1 & & & 1 & & \\
\hline \multirow[t]{2}{*}{ PO surgical complication } & Yes & 1.05 & $0.46-2.48$ & .94 & & & \\
\hline & No & 1 & & & & & \\
\hline \multirow[t]{2}{*}{ Blood transfusion } & Yes & 5.18 & $1.58-17.00$ & .07 & 5.59 & $1.47-21.26$ & .012 \\
\hline & No & 1 & & & 1 & & \\
\hline \multirow[t]{2}{*}{ Period of the study } & 1989-1997 & 1 & & & & & \\
\hline & $1998-2003$ & 1.62 & $0.59-4.41$ & .35 & & & \\
\hline
\end{tabular}

$O R$, Odds ratio; $C l$, confidence interval; $R T$, radiotherapy; $E P R$, extrapericardial route; $I P R$, intrapericardial route; $P O$, postoperative. *Estimates obtained by running the model with one independent variable at a time.

directly in relation to this medical therapy. They represented 1 pneumothorax and 1 hemoptysis by tumoral necrosis. For the 98 other patients, the surgical intervention was performed from 4 to 8 weeks after the completion of medical therapy.

There were 55 right and 45 left resections. The surgical approaches were a posterolateral thoracotomy in 88 patients, a lateral thoracotomy in 11 patients, and a sternotomy in 1 patient. The intrapericardial route was used in 85 patients. The procedure was extended to one of the following structures: superior vena cava $(\mathrm{n}=3)$, aorta $(\mathrm{n}=1)$, left atrium $(n=2)$, carina $(n=4)$, chest wall $(n=1)$, subclavian artery $(n=1)$, and esophagus $(n=1)$.

The main bronchus was stapled in 81 patients and hand sutured in 19 patients (interrupted stitches in 15 and running sutures in 4 patients). The bronchial stump was reinforced in 57 patients with a pedicled parietal pleural flap in 25 patients, mediastinal fatty tissues from the thymic area in 14 patients, a pedicled muscle in 15 patients, and pericardium in 3 patients, with the difference relating to operator preference only. The bronchial stump was covered 48 times on the right side (87\%) and 9 times on the left side (20\%). Each resection included an ipsilateral mediastinal lymphadenectomy. Complete resection (R0) was achieved in 94 patients.
For the remaining patients, 2 had a macroscopic residual tumor (R2), and 4 had a microscopic residual tumor found on specimen analysis (R1). Postoperative pathologic study of the specimen showed no tumor cells in 8 patients, 10 stage IA tumors, 9 stage IB tumors, 7 stage IIA tumors, 15 stage IIB tumors, 25 stage IIIA tumors, 19 stage IIIB tumors, and 7 stage IV tumors.

\section{Postoperative Mortality}

The 30 -day mortality rate was $12 \%$. This rate according to the right side/left side distribution was, respectively, $16.4 \%$ / $6.7 \%(P=.14)$. Causes of death were as follows: postpneumonectomy edema-adult respiratory distress syndrome (n $=5)$, bronchial fistula $(\mathrm{n}=2)$, myocardial infarction $(\mathrm{n}=$ 1), pulmonary embolism occurring from a superior vena caval graft occlusion $(\mathrm{n}=1)$, acute right cardiac failure $(\mathrm{n}$ $=1)$, hemorrhagic shock $(\mathrm{n}=1)$, and sepsis shock $(\mathrm{n}=1)$. Thirty-day mortality with reference to various variables is shown in Table 1.

The 90 -day mortality rate was $21 \%$. This rate according to the right side/left side distribution was, respectively, $25.5 \% / 15.5 \%(P=.18)$. Ninety-day mortality with reference to various variables is mentioned in Table 2. Causes of the 9 additional deaths were as follows: recurrence disease 
TABLE 4. Variables predicting postoperative cardiovascular events

\begin{tabular}{|c|c|c|c|c|c|c|c|}
\hline \multirow[b]{2}{*}{ Variable } & \multirow[b]{2}{*}{ Levels } & \multirow{2}{*}{$\begin{array}{c}\text { Crude } \mathrm{OR}^{*} \\
\text { estimate }\end{array}$} & \multirow[b]{2}{*}{$95 \% \mathrm{Cl}$} & \multicolumn{3}{|c|}{ Adjusted OR } & \multirow[b]{2}{*}{$P$ value } \\
\hline & & & & $P$ value & estimate & $95 \% \mathrm{Cl}$ & \\
\hline \multirow[t]{2}{*}{ Age } & $\leq 60$ y & 1 & & & & & \\
\hline & $>60 y$ & 2.03 & $0.79-5.17$ & .14 & & & \\
\hline \multirow[t]{2}{*}{ Sex } & Male & 1.10 & $0.32-3.75$ & .88 & & & \\
\hline & Female & 1 & & & & & \\
\hline \multirow[t]{2}{*}{ Preoperative RT } & Yes & 1 & & & & & \\
\hline & No & 1.49 & $0.53-4.21$ & .45 & & & \\
\hline \multirow[t]{2}{*}{ Resection } & Standard & 1 & & & & & \\
\hline & Extended & 3.07 & $0.92-10.22$ & .07 & & & \\
\hline \multirow[t]{2}{*}{ Operation } & EPR & 1 & $0.37-3.08$ & .89 & & & \\
\hline & IPR & 1.07 & & & & & \\
\hline \multirow[t]{2}{*}{ Side of resection } & Right & 1.31 & $0.52-3.29$ & .56 & & & \\
\hline & Left & 1 & & & & & \\
\hline \multirow[t]{2}{*}{ Bronchial suture reinforcement } & Yes & 1.86 & $0.72-4.83$ & .20 & & & \\
\hline & No & 1 & & & & & \\
\hline \multirow[t]{2}{*}{ Pathologic stage } & $0, \mathrm{I}, \mathrm{II}$ & 1 & & & & & \\
\hline & III, IV & 1.06 & $0.43-2.61$ & .9 & & & \\
\hline \multirow[t]{2}{*}{ PO respiratory event } & Yes & 4.89 & $1.69-14.12$ & .003 & 3.47 & $1.09-10.95$ & .03 \\
\hline & No & 1 & & & 1 & & \\
\hline \multirow[t]{2}{*}{ PO surgical complication } & Yes & 1.40 & $0.39-5.00$ & .61 & & & \\
\hline & No & 1 & & & & & \\
\hline \multirow[t]{2}{*}{ Blood transfusion } & Yes & 3.65 & $1.36-9.79$ & .01 & 2.88 & $0.99-8.40$ & .05 \\
\hline & No & 1 & & & 1 & & \\
\hline \multirow[t]{2}{*}{ Period of the study } & 1989-1997 & 1 & & & 1 & & \\
\hline & 1998-2003 & 3.16 & $1.23-8.11$ & .02 & 3.18 & $1.16-8.74$ & .03 \\
\hline
\end{tabular}

$O R$, Odds ratio; $C l$, confidence interval; $R T$, radiotherapy; $E P R$, extrapericardial route; $I P R$, intrapericardial route; $P O$, postoperative. *Estimates obtained by running the model with one independent variable at a time.

in 4 patients, fungal sepsis shock (Candida species) in 1 patient, chronic respiratory failure in 1 patient, and unknown in 3 patients.

The adjuvant therapy did not contribute to the 90-day mortality because among the 21 patients who died within 3 months postoperatively, only one had adjuvant radiotherapy.

\section{Postoperative Respiratory Event}

Nineteen patients presented with one or more postoperative respiratory events of very variable gravity without technical and surgical complication. These were represented by bronchopulmonary obstruction $(\mathrm{n}=12)$, atelectasis $(n=6)$, postpneumonectomy edema-adult respiratory distress syndrome $(n=6)$, pneumothorax in the remaining lung $(\mathrm{n}=1)$, pulmonary embolism $(\mathrm{n}=2)$, and pneumonia $(\mathrm{n}=11)$. Among these 11 cases of pneumonia, there were 3 cases of cytomegalovirus-induced pneumonia, the diagnosis of which had been obtained on the basis of a positive viremy in addition of positive cultures from bronchoalveolar lavage. The relationship between variables and respiratory events is shown in Table 3.

\section{Postoperative Cardiovascular Event}

Twenty-five patients experienced one or more cardiovascular events without surgical complication during the postoperative course. These were as follow: arrhythmia $(\mathrm{n}=19)$, cardiac failure $(\mathrm{n}=3)$, myocardial infarction $(\mathrm{n}=1)$, deep vein thrombosis $(\mathrm{n}=2)$, and stroke $(\mathrm{n}=2)$. The relationship between variables and cardiovascular events is shown in Table 4.

\section{Postoperative Surgical Complications}

Thirteen patients had a surgical complication. There were 6 hemothoraxes, 6 bronchopleural fistulas, and 1 cardiac luxation. Seven patients required a reoperation: 5 for bronchial fistula, 1 for cardiac luxation, and 1 for hemothorax.

\section{Hemorrhagic Risk}

Forty-nine patients were transfused (allogeneic blood transfusion) with, on average, $5 \pm 3$ cell packs.

\section{Bronchial Fistula}

Six patients had an early bronchial fistula. This complication represented $9 \%$ versus $2 \%$ of the patients who underwent a 
TABLE 5. Relationship between variables and 5-year survivals for patients undergoing pneumonectomy after an induction therapy

\begin{tabular}{|c|c|c|c|c|c|}
\hline \multirow[b]{2}{*}{ Variable } & \multicolumn{2}{|c|}{ No. of observations } & \multicolumn{2}{|c|}{$95 \% \mathrm{CI}$} & \multirow[b]{2}{*}{$P$ value } \\
\hline & $(n=100)$ & $5 y$ & Lower & Upper & \\
\hline \multicolumn{6}{|l|}{ Age } \\
\hline$\leq 60 \mathrm{y}$ & 49 & $20.8 \%$ & $14.2 \%$ & $27.4 \%$ & .18 \\
\hline$>60 \mathrm{y}$ & 51 & $18.7 \%$ & $12.1 \%$ & $25.3 \%$ & \\
\hline \multicolumn{6}{|l|}{ Sex } \\
\hline Male & 83 & $18.3 \%$ & $13.3 \%$ & $23.3 \%$ & .69 \\
\hline Female & 17 & $25.4 \%$ & $13.4 \%$ & $37.4 \%$ & \\
\hline \multicolumn{6}{|l|}{ Preoperative radiotherapy } \\
\hline Yes & 30 & $37 \%$ & $27.6 \%$ & $46.4 \%$ & .14 \\
\hline No & 70 & $10.4 \%$ & $5.9 \%$ & $14.9 \%$ & \\
\hline \multicolumn{6}{|l|}{ Resection } \\
\hline Standard & 87 & $21.2 \%$ & $16.1 \%$ & $26.3 \%$ & .05 \\
\hline Extended & 13 & $9.6 \%$ & $0.7 \%$ & $19.7 \%$ & \\
\hline \multicolumn{6}{|l|}{ Operation } \\
\hline Extrapericardial route & 15 & $6 \%$ & $0.3 \%$ & $11.7 \%$ & .44 \\
\hline Intrapericardial route & 85 & $24.1 \%$ & $18.5 \%$ & $29.7 \%$ & \\
\hline \multicolumn{6}{|l|}{ Side of resection } \\
\hline Right & 55 & $18.9 \%$ & $13 \%$ & $24.8 \%$ & .66 \\
\hline Left & 45 & $20.8 \%$ & $13.6 \%$ & $28 \%$ & \\
\hline \multicolumn{6}{|c|}{ Bronchial suture reinforcement } \\
\hline Yes & 57 & $26.7 \%$ & $19.6 \%$ & $33.2 \%$ & .30 \\
\hline No & 43 & $12.5 \%$ & $7.1 \%$ & $17.9 \%$ & \\
\hline \multicolumn{6}{|l|}{ Pathology stage } \\
\hline $0, \mathrm{I}, \mathrm{II}$ & 49 & $26.3 \%$ & $18.9 \%$ & $33.7 \%$ & .08 \\
\hline III, IV & 51 & $13.3 \%$ & $7.9 \%$ & $18.7 \%$ & \\
\hline \multicolumn{6}{|c|}{ Postoperative respiratory event } \\
\hline Yes & 19 & $20.5 \%$ & $9.5 \%$ & $31.5 \%$ & .07 \\
\hline No & 81 & $20.6 \%$ & $14.6 \%$ & $26.6 \%$ & \\
\hline \multicolumn{6}{|c|}{ Postoperative cardiovascular event } \\
\hline Yes & 25 & $9 \%$ & $0 \%$ & $18 \%$ & .004 \\
\hline No & 75 & $22.4 \%$ & $17.4 \%$ & $27.4 \%$ & \\
\hline \multicolumn{6}{|c|}{ Postoperative surgical complication } \\
\hline Yes & 13 & $7 \%$ & $0 \%$ & $14 \%$ & .03 \\
\hline No & 87 & $21.9 \%$ & $16.9 \%$ & $26.9 \%$ & \\
\hline \multicolumn{6}{|l|}{ Blood transfusion } \\
\hline Yes & 49 & $19 \%$ & $12.6 \%$ & $25.4 \%$ & .08 \\
\hline No & 51 & $21.2 \%$ & $14.5 \%$ & $27.9 \%$ & \\
\hline \multicolumn{6}{|l|}{ Period of the study } \\
\hline 1989-1997 & 57 & $20.3 \%$ & $14.9 \%$ & $25.7 \%$ & .89 \\
\hline 1998-2003 & 43 & $23.4 \%$ & $15 \%$ & $31.8 \%$ & \\
\hline
\end{tabular}

$\mathrm{Cl}$, Confidence interval.

right versus left resection, respectively $(P=.15)$. All bronchial fistulas occurred within the first 30 days after the operation. Two (33\%) patients died, both from respiratory failure.

Six empyemas occurred in otherwise healthy discharged patients within the first 3 months after the pneumonectomy: 1 was related to esophagopleural fistula, and 2 to were related bronchopleural fistula. The results of esophageal and bronchial fiberoscopies were normal in the remaining 3 patients.

\section{Survival}

Survival information was obtained for all patients. At completion of the study, 25 patients were alive, and 75 were dead. The median follow-up for the survivors was 21 months (mean, $39 \pm 7$ months). Their clinical status was as follow: alive and well $(84 \%)$ and alive with disease $(16 \%)$. The cause of death was related to the operation in $16 \%$ of cases and to the lung cancer in $49 \%$. Cancer-unrelated deaths accounted for $11 \%$ of all deaths. 
TABLE 6. Relationship between variables and 5-year survivals in 90-day survivors

\begin{tabular}{|c|c|c|c|c|c|}
\hline \multirow[b]{2}{*}{ Variable } & \multicolumn{2}{|c|}{ No. of observations } & \multicolumn{2}{|c|}{$95 \% \mathrm{Cl}$} & \multirow[b]{2}{*}{$P$ value } \\
\hline & $(\mathrm{n}=79)$ & $5 y$ & Lower & Upper & \\
\hline \multicolumn{6}{|l|}{ Age } \\
\hline$\leq 60 y$ & 46 & $22.1 \%$ & $15.2 \%$ & $29 \%$ & .5 \\
\hline$>60 y$ & 33 & $29.4 \%$ & $19.2 \%$ & $39.3 \%$ & \\
\hline \multicolumn{6}{|l|}{ Sex } \\
\hline Male & 63 & $24.2 \%$ & $17.8 \%$ & $30.6 \%$ & .58 \\
\hline Female & 16 & $27 \%$ & $14.4 \%$ & $39.6 \%$ & \\
\hline \multicolumn{6}{|l|}{ Preoperative radiotherapy } \\
\hline Yes & 23 & $48.5 \%$ & $37.3 \%$ & $59.7 \%$ & .05 \\
\hline No & 56 & $13.1 \%$ & $7.5 \%$ & $18.7 \%$ & \\
\hline \multicolumn{6}{|l|}{ Resection } \\
\hline Standard & 70 & $26.4 \%$ & $20.2 \%$ & $32.6 \%$ & .07 \\
\hline Extended & 9 & $13.8 \%$ & $1.1 \%$ & $26.5 \%$ & \\
\hline \multicolumn{6}{|l|}{ Operation } \\
\hline Extrapericardial route & 18 & $8.3 \%$ & $0.4 \%$ & $16.2 \%$ & .7 \\
\hline Intrapericardial route & 61 & $29.7 \%$ & $23.1 \%$ & $36.3 \%$ & \\
\hline \multicolumn{6}{|l|}{ Side of resection } \\
\hline Right & 41 & $25.6 \%$ & $17.8 \%$ & $33.4 \%$ & .74 \\
\hline Left & 38 & $24.7 \%$ & $16.4 \%$ & $33 \%$ & \\
\hline \multicolumn{6}{|c|}{ Bronchial suture reinforcement } \\
\hline Yes & 43 & $35.6 \%$ & $26.6 \%$ & $44.6 \%$ & .05 \\
\hline No & 36 & $14.9 \%$ & $8.5 \%$ & $21.3 \%$ & \\
\hline \multicolumn{6}{|l|}{ Pathology stage } \\
\hline $0, I, I I$ & 38 & $34.1 \%$ & $24.9 \%$ & $43.3 \%$ & .01 \\
\hline III, IV & 41 & $16.6 \%$ & $10.1 \%$ & $23.1 \%$ & \\
\hline \multicolumn{6}{|c|}{ Postoperative respiratory event } \\
\hline Yes & 11 & $37 \%$ & $18.2 \%$ & $45.8 \%$ & .95 \\
\hline No & 68 & $24.6 \%$ & $18.7 \%$ & $30.5 \%$ & \\
\hline \multicolumn{6}{|c|}{ Postoperative cardiovascular event } \\
\hline Yes & 13 & $19.1 \%$ & $2.5 \%$ & $35.7 \%$ & .91 \\
\hline No & 66 & $25.5 \%$ & $19.5 \%$ & $31.5 \%$ & \\
\hline \multicolumn{6}{|c|}{ Postoperative surgical complication } \\
\hline Yes & 8 & $12.5 \%$ & $0.8 \%$ & $24.2 \%$ & .14 \\
\hline No & 71 & $27 \%$ & $20.8 \%$ & $33.2 \%$ & \\
\hline \multicolumn{6}{|l|}{ Blood transfusion } \\
\hline Yes & 33 & $28.2 \%$ & $19.2 \%$ & $37.2 \%$ & .85 \\
\hline No & 46 & $23.5 \%$ & $16.2 \%$ & $30.8 \%$ & \\
\hline \multicolumn{6}{|l|}{ Period of the study } \\
\hline 1989-1997 & 45 & $25.7 \%$ & $19.1 \%$ & $32.3 \%$ & .88 \\
\hline 1998-2003 & 34 & $23.4 \%$ & $19.5 \%$ & $40.3 \%$ & \\
\hline
\end{tabular}

$\mathrm{Cl}$, Confidence value.

The cause of death was not documented in $24 \%$ of cases. Among the 41 patients who experienced recurrence of their lung cancer, 32 (78\%) had distant metastases, and 9 (22\%) had a locoregional recurrence as the first site of recurrence.

Estimated overall survival rates from the date of the operation and including the operative mortality, as well as any cancer-related and unrelated deaths, were $27.8 \%$ (range, $22.9 \%-32.7 \%$ ) and $19.8 \%$ (range, $15.2 \%-24.4 \%$ ) at 3 and 5 years, respectively. Survival with reference to various variables is shown in Table 5. At multivariate analysis, 2 independent prognostic factors entered the model: postoperative cardiovascular event (relative risk [RR], 2.29; 95\% confidence interval $[\mathrm{CI}], 1.35-3.91 ; P=.002)$ and postoperative surgical complication (RR, 2.13; 95\% CI, 1.16-3.91; $P=.015)$. Estimated overall survival rates in 90-day survivors were $35 \%$ (range, 29\%-41\%) and 25\% (range, $19.3 \%-30.7 \%$ ) at 3 and 5 years, respectively. This survival with reference to various variables is shown in Table 6. At multivariate analysis, one independent prognostic factor entered the model: pathologic stage III-IV disease (RR, 1.89 ; 95\% CI, 1.09-3.26; $P=.022$ ). 


\section{Discussion}

Thirty-day mortality observed in this series (12\%) is in line with internationally reported data on lung cancer surgery in the setting of induction therapy. ${ }^{10,12,16,18}$ It is also in accordance with the risk of pneumonectomy as estimated from nationwide data, including in high-volume hospitals $(10.7 \%)$, that is considerably higher than those typically reported. ${ }^{20}$ However, this rate seems higher than what is currently reported after an operation alone by single institutions or multicenter databases, ${ }^{21-23}$ suggesting an increased risk caused by the preoperative oncologic therapy.

Neither 30-day nor 90-day mortality rates improved with time in our experience. Unsurprisingly, the spectrum of major complications included various surgical, as well as medical, complications. However, our results show that surgical complications were not the most determining causes of fatality in contrast with cardiopulmonary complications. Indeed, cardiac and pulmonary events occurring in the absence of a concomitant surgical complication were shown to be strong and independent predictors of mortality. Multivariate analyses suggest that both events were often associated concurrently or sequentially and correlated with allogeneic blood transfusions. Because blood requirements after major operations mainly depend on preoperative hemoglobin levels ${ }^{24}$ it might be anticipated that induction therapy and anemia logically increase these needs. This fact is of clinical relevance because data on transfusion therapy have not always been favorable, particularly in the areas of postoperative infection, systemic inflammatory response syndrome, multiple organ failure, and finally mortality. Furthermore, the risk of infection transmission now includes both existing and emerging pathogens. Of note, some patients had a well-documented viral pneumonia, a cause that is not common after surgical intervention alone. This fact also suggests an immunosuppressive side effect induced by the preoperative treatment. Cardiac events appeared to be more frequent in the recent period of the study. One might hypothesize that such complications strongly depend on the preoperative cardiac status, and this observation becomes consistent with the constant aging of the surgical population and its related comorbidities.

Even if it did not reach statistical significance, there was an obvious difference according to the side of the procedure, with a 2 -fold increase of the operative risk for right pneumonectomy. The same excess of 30-day mortality after right pneumonectomy after induction therapy has been already reported by Sloan Kettering Memorial ${ }^{18}$ and might be explained by a magnification of the higher risk of bronchial fistula and respiratory failure of right-sided procedures over left-sided ones performed without any preoperative treatment. ${ }^{25}$ Of concern is also the fact that the mortality rate considered on a 90-day basis was about twice as high as that observed within the first 30 postoperative days. Our 90-day mortality rate was very similar to that reported for right pneumonectomy after induction therapy by Martin and colleagues. ${ }^{18}$ The majority of the 90-day deaths $(57 \%)$ were related to postoperative complications. Nevertheless, 1 of 5 patients dies from the initial tumor disease. Generally this was represented by brain metastasis (75\%). This concerned patients in the beginning period of our study (1989-1997) who did not have a routine brain CT scan performed as part of the pretherapeutic workup. These patients had cerebral edema during the early postoperative course related to undiagnosed brain metastases. Also, the incidence of sudden deaths with unknown origin in otherwise healthy discharged patients was substantial (14\%). In our opinion, some of them might have been due to pulmonary embolism, which is a frequent cause of acute fatality after lung resection. ${ }^{26}$ This might support the use of vitamin $\mathrm{K}$ antagonist in the long run.

This study has the obvious limitations of a retrospective study because of data collection. We mixed preoperative, intraoperative, and postoperative variables in the analysis to identify potential predictors of mortality. It might be objected that some potentially pertinent variables were missing, such as spirometric data. However, our selection criteria for pneumonectomy have been rather standardized during the period and led to a very homogeneous surgical cohort from this point of view. It would have been also of great interest to incorporate cardiac and respiratory exercise stress testing findings, as well as comorbidity scores, or any other clinically relevant markers as documented by the current literature. Unfortunately, the modalities of such tests and scores appeared or changed radically along the period, resulting in a high amount of missing data and rendering the analysis unsound. Obviously, postoperative variables are not available at the moment of the patient selection for surgical intervention. However, we opted deliberately for a very pragmatic approach that evaluated also what kind of early postoperative events might have been predictive of delayed complications.

Despite controversial results of available randomized trials, ${ }^{2,3}$ combined strategies with induction therapy are currently applied worldwide for the management of patients with advanced-stage NSCLC to improve survival. Indeed, all our patients presented with a locally advanced or metastatic disease, even if this statement was documented pathologically in only one third of the patients before the induction treatment. The indication and modalities of the induction therapy were decided by the multidisciplinary oncologic committee of our institution with the following rationales: (1) even if there are contradictory data in the literature regarding the value of induction therapy in stage IIIA disease, any patient with resectable N2 disease is considered a candidate for induction therapy, except if he or she accepts to be enrolled in a clinical trial; (2) any T4 N0 
tumor suspected to be completely resectable is referred to surgical intervention with or without induction chemotherapy or radiochemotherapy; and (3) because there are no clear guidelines for the treatment of patients with stage IV disease, particularly in the setting of a completely resected single brain metastasis, the treatment discussion remains open. We opted to consider that the disease had been downstaged by the neurosurgeon and that the treatment of the lung cancer had to be based on the residual disease, provided that $\mathrm{N} 2$ involvement had been ruled out by the use of mediastinoscopy. We postulated that the overall prognosis of the highly selected population of patients with lung cancer presenting with a resectable primary lung tumor and an apparently solitary brain metastasis was at the same level as that of patients presenting with a locally advanced disease in whom the problem is the presence of a disseminated micrometastatic disease in almost all the cases.

Of interest is the fact that our patients experienced very similar 3- and 5-year survival rates as those seen in currently available studies with multimodal therapies for NSCLC. The substantial overall 5-year survival rate $(19.8 \%)$ we observed reflects patient selection comparable with that reported worldwide..$^{1,7,13,18,27,28}$ To the best of our knowledge, however, this is the first report that deals specifically with the results of pneumonectomy in that setting. In turn, few data are available to analyze our results comprehensively. The risk/benefit ratio associated with the procedure is difficult to assess. The fact that the occurrence of postoperative complications was the single prognosticator of long-term survival at the multivariate analysis performed on the whole series of patients highlights the necessity to consider first the toxicity of combined modalities. Interestingly, the multivariate analysis limited to the 90-day survivors disclosed downstaging as the sole prognosticator of long-term survival in accordance with the results of recent prospective trials. $^{6,29,30}$ Thus our results strongly suggest that postinduction restaging is of paramount importance to avoid pneumonectomy in nonresponders.

\section{Conclusion}

Pneumonectomy after induction therapy is a high-risk procedure, the survival benefit of which appears uncertain. This observation leads to consideration of alternative therapeutic options, such as radiotherapy or bronchial, arterial, or both sleeve lobectomies whenever technically possible, especially in patients with a right-sided disease for whom the risk to die within 90 days after surgical intervention is at the same level as the hope of cure.

\section{References}

1. Vansteenkiste J, De Leyn P, Deneffe G, Stalpaert G, Nackaerts KL, Lerut TE, et al. Present status of induction treatment in stageIIIA-N2 non-small cell lung cancer: a review. Eur J Cardiothorac Surg. 1998; 13:1-12.
2. Rosell R, Gomez-Codina J, Camps C, Javier Sanchez J, Maestre J, Padilla J, et al. Preresectional chemotherapy in stage IIIA non-smallcell lung cancer: a 7-year assessment of a randomized controlled trial. Lung Cancer. 1999;26:7-14.

3. Roth JA, Atkinson EN, Fossella F, Komaki R, Ryan MB, Putnam JB $\mathrm{Jr}$, et al. Long-term follow-up of patients enrolled in a randomized trial comparing perioperative chemotherapy and surgery with surgery alone in resectable stage IIIA non-small-cell lung cancer. Lung Cancer. 1998;21:1-6.

4. Yoneda S, Hibino S, Gotoh I, Sakai H, Noguchi Y, Yamamoto M. A comparative trial on induction chemotherapy followed by surgery (CRS) or immediate surgery (IS) for stage III NSCLC [abstract]. Proc Am Soc Clin. 1995;14:A1128.

5. Depierre A, Milleron B, Moro-Sibilot D, Chevret S, Quoix E, Lebeau $\mathrm{B}$, et al. Preoperative chemotherapy followed by surgery compared with primary surgery in resectable stage I (except T1N0), II, and IIIa non-small-cell lung cancer. J Clin Oncol. 2002;20:247-53.

6. Betticher DC, Hsu Schmitz SF, Totsch M, Hansen E, Joss C, von Briel $\mathrm{C}$, et al. Mediastinal lymph node clearance after docetaxel-cisplatin neoadjuvant chemotherapy is prognostic of survival in patients with stage IIIA pN2 non-small-cell lung cancer: a multicenter phase II trial. J Clin Oncol. 2003;21:1752-9.

7. Doddoli C, Thomas P, Thirion X, Serée Y, Giudicelli R, Fuentes P. Postoperative complications in relation with induction therapy for lung cancer. Eur J Cardiothorac Surg. 2001; 20:385-90.

8. Deutsch M, Crawford J, Leopold K, Wolfe W, Foster W, Herndon J, et al. Phase II study of neoadjuvant chemotherapy and radiation therapy with thoracotomy in the treatment of clinically staged IIIA non-small cell lung cancer. Cancer. 1994;74:1243-52.

9. Fowler WC, Langer CJ, Curran WJ, Keller SM. Post operative complications after combined protoadjuvant treatment of lung cancer. Ann Thorac Surg. 1993;55:986-90.

10. Regnard JF, Icard P, Deneuville M, Jauffret B, Magdeleinat P, Levi $\mathrm{JF}$, et al. Lung resection after high doses of mediastinal radiotherapy (sixty grays or more). Reinforcement of bronchial healing with thoracic muscle flaps in nine cases. J Thorac Cardiovasc Surg. 1994;107:607-10.

11. Galetta D, Cesario A, Margaritora S, Porziella V, Macis G, D'Angelillo RM, et al. Enduring challenge in the treatment of nonsmall cell lung cancer with clinical stage IIIB: results of a trimodality approach. Ann Thorac Surg. 2003;76:1802-8.

12. Martini N, Kris MG, Flehinger BJ, Gralla RJ, Bains MS, Burt ME, et al. Preoperative chemotherapy for stage IIIA (N2): the Sloan-Kettering experience with 136 patients. Ann Thorac Surg. 1993;55:1365-74.

13. Rice TW, Adelstein DJ, Koka A, Tefft M, Kirby TJ, Van Kirk MA, et al. Accelerated induction therapy and resection for poor prognosis stage III non-small cell lung cancer. Ann Thorac Surg. 1995; 60:586-92.

14. Rusch VW, Albain KS, Crowley JJ, Rice TW, Lonchyna V, McKenna $R$, et al. Neoadjuvant therapy: a novel and effective treatment for stage IIIB non-small cell lung cancer. Ann Thorac Surg. 1994;58:290-5.

15. Sugarbaker DJ, Herndon J, Kohman LJ, Krasna MK, Green MR, the Cancer and Leukemia Group B Thoracic Surgery Group. Results of cancer and leukemia group B protocol 8935. A multiinstitutional phase II trimodality trial for stage IIIA (N2) non-small cell lung cancer. J Thorac Cardiovasc Surg. 1995;109:473-85.

16. Macchiarini P, Chevalier AR, Monnet I, Vannetzel JM, Rebischung JL, Cerrina J, et al. Extended operations after induction therapy for stage IIIB (T4) non-small cell lung cancer. Ann Thorac Surg. 1994; 57:966-73.

17. Novoa N, Varela G, Jimenez MF. Morbidity after surgery for nonsmall cell lung carcinoma is not related to neoadjuvant chemotherapy. Eur J Cardiothorac Surg. 2001;20:700-4.

18. Martin J, Ginsberg RJ, Abolhoda A, Bains MS, Downey RJ, Korst RJ, et al. Morbidity and mortality after neoadjuvant therapy for lung cancer: the risks of right pneumonectomy. Ann Thorac Surg. 2001;72:1149-54.

19. Stamatis G, Djuric D, Eberhardt W, Pöttken C, Zaboura G, Fechner S, et al. Postoperative morbidity and mortality after induction chemoradiotherapy for locally advanced lung cancer: an analysis of 350 operated patients. Eur J Cardiothorac Surg. 2002;22:292-7. 
20. Birkmeyer JD, Siewers AE, Finlayson EV, Stukel TA, Lucas FL, Batista I, et al. Hospital volume and surgical mortality in the United States. N Engl J Med. 2002;346:1128-37.

21. Mitsudomi T, Mizoue T, Yoshimatsu T, Oyama T, Nakanishi R, Okabayashi $\mathrm{K}$, et al. Postoperative complications after pneumonectomy for treatment of lung cancer: multivariate analysis. J Surg Oncol. 1996;61:218-22.

22. Harpole DH, Liptay MJ, DeCamp MM Jr, Mentzer SJ, Swanson SJ, Sugarbaker DJ. Prospective analysis of pneumonectomy: risk factors for major morbidity and cardiac dysrhythmias. Ann Thorac Surg. 1996;61:977-82.

23. Wada H, Nakamura T, Nakamoto K, Maeda M, Watanabe Y. Thirtyday operative mortality for thoracotomy in lung cancer. J Thorac Cardiovasc Surg. 1998;115:70-3.

24. Cirasino L, Barosi G, Torre M, Crespi S, Colombo P, Belloni PA. Preoperative predictors of the need for allogeneic blood transfusion in lung cancer surgery. Transfusion. 2000;40:1228-34.

25. Kopec SE, Irwin RS, Umali-Torres CB, Balikian JP, Conlan AA. The postpneumonectomy state. Chest. 1998;114:1158-84.
26. Kalweit G, Huwer H, Volkmer I, Petzold T, Gams E. Pulmonary embolism: a frequent cause of acute fatality after lung resection. Eur J Cardiothorac Surg. 1996;10:242-6.

27. Perry MC, Deslauriers J, Albain KS, Choi NC, Depierre A, Johnston $\mathrm{MR}$, et al. Induction treatment for resectable non-small cell lung cancer. Lung Cancer. 1997;17(suppl):S15-8.

28. Martin J, Ginsberg RJ, Venkatraman ES, Bains MS, Downey RJ, Korst RJ, et al. Long-term results of combined-modality therapy in resectable non-small-cell lung cancer. J Clin Oncol. 2002;20:198995.

29. Okada M, Tsubota N, Yoshimura M, Miyamoto Y, Matsuoka H. Induction therapy for non-small cell lung cancer with involved mediastinal nodes in multiple stations. Chest. 2000;118:123-8.

30. Voltolini L, Luzzi L, Ghiribelli C, Paladini P, Di Bisceglie M, Gotti G. Results of induction chemotherapy followed by surgical resection in patients with stage IIIA (N2) non-small cell lung cancer: the importance of the nodal down-staging after chemotherapy. Eur J Cardiothorac Surg. 2001;20:1106-12.

\section{Availability of Journal back issues}

As a service to our subscribers, copies of back issues of The Journal of Thoracic and Cardiovascular Surgery for the preceding 5 years are maintained and are available for purchase from Elsevier Inc. until inventory is depleted. Please write to Elsevier Inc.,Subscription Customer Service, 6277 Sea Harbor Dr, Orlando, FL 32877, or call $800-654-2452$ or $407-345-4000$ for information on availability of particular issues and prices. 